\title{
Landscape Dynamics in the Eemian Interglacial and Early Weichselian Glacial Epoch on the South Valdai Hills (Russia)
}

\author{
E.Yu. Novenko* and I.S. Zuganova
}

Institute of Geography Russian Academy of Science, 119017, Moscow, Staromonetny, 29, Russia

\begin{abstract}
The paper presents new results of detail pollen and macrofossil investigation of Late Pleistocene deposits in the Central Forest State Natural Biosphere Reserve (the south of Valdai Hills). According to obtained data the Eemian (Mikulino) Interglacial, the Weichselian (Valdai) glacial deposits occur in the territory of the Reserve. The main trends of landscape development were determined both by changes of pollen and macrofossil assemblages and on the base of analysis of fossil flora using Ellenberg's scale. The typical forest successions of the Eemian Interglacial and short-term phases in the Interglacial \Glacial transition have been determined. The first post-Eemian cooling comprised several short stages of cooling and weak climatic ameliorations that point to general climatic instability in the initial part of this glacial epoch.
\end{abstract}

Keywords: East Europe, pollen data, macrofossil, Eemian, Early Weichselian, palaeo-environmental reconstruction.

\section{INTRODUCTION}

The landscape dynamics during the last interglacial (Eemian, Mikulino) and the transitional phases to subsequent glacial epoch is a one of the important problems in Quaternary researches, being a possible analogue to the present environment situation. As the Eemian interval is beyond the range of radiocarbon dating, precise dating of interglacial records is still problematic. According to paleogeographical data, the Eemian Interglacial corresponds to Marine Isotope Stage 5e [1], beginning of which is assigned to $126 \mathrm{kyr}$ BP. Usually age-dept model of Eemian profiles is based on correlation with other proxies: stable isotope data from deep ice core [2], annual layer counting of lake sediments or stalagmites data [3-5]. The first postEemian cooling is attributed to MIS $5 \mathrm{~d}-5 \mathrm{a}$, the time interval 115-75 kyr BP.

Late Pleistocene interglacial deposits in the region of the south Valdai Hills has long attracted a great attention of researchers [6], complete Eemian/Early Weichselian sediment sequences have been described in a number of sites. During the last 10 years this region has been studied by the Institute of Ecology and Evolution RAS and by the Institute of Geography RAS. The studies have shown that geological and geomorphologic conditions of the territory give a unique possibility of detail analysis of landscape dynamics in Interglacial $\backslash$ Glacial transition.

\section{STUDY AREA}

The Central Forest State Natural Biosphere Reserve (CFSNBR) is situated at the distance of $360 \mathrm{~km}$ westwards from Moskow (the Tver' region) in the south of the Valdai Hills (Fig. 1). In the 1985 the Reserve was included into the

*Address correspondence to this author at the Institute of Geography Russian Academy of Science, 119017, Moscow, Staromonetny, 29. Russia; Tel: +7 (499) 23802 98; Fax: +7 (495) 95900 33; E-mail: lenanov@mail.ru international network of UNESCO biosphere reserves. This territory is located in the marginal part of the Weichselian ice sheet, in the transitional zone from southern taiga to mixed coniferous-broadleaf forests. The vegetation cover is represented by primary (not affected by human activity) forest (southern taiga type) and swamp ecosystems.

The climate of the region is continental with relatively mild winter and warm summer. According to meteorological observation within the CFSNBR (the meteorological station exists here since 1963), the main climatic parameters are as follows: mean July temperature is $17^{\circ} \mathrm{C}$, that of January is $10^{\circ} \mathrm{C}$, mean annual temperature is $3.8^{\circ} \mathrm{C}$. Being close to the center of the East European Plain, the territory receives 700 $\mathrm{mm}$ precipitations per year, more than a half of that occurs in the summer-autumn period as rain and the other part during winter and spring as snow.

The detail paleobotanical researches were carried out for a borehole $8 \mathrm{~m}$ in depth in the south-east of the Reserve (N $56^{\circ} 35^{\prime}$ E $\left.32^{\circ} 55^{\prime}\right)$. The series of peat and clay lie on a till of the Saalian (Dnieper, Moscow stage) glaciation (Fig. 2). The upper part of the section (Holocene sequence) is separated from buried organic deposits by thin $(15 \mathrm{~cm})$ horizon of loess-like sediments. The late Holocene deposits consist of peat layers (65 $\mathrm{cm}$ in total) and lacustrine sediments (up 40 $\mathrm{cm})$.

\section{METHOD}

The field work comprised detailed sampling using Eijelkamp coring equipment. Steel sample tubes were pushed into the sediments that allow us to obtained undisturbed samples. The bore specimens were subsample for pollen analysis with interval $10 \mathrm{~cm}$. The additional borehole was made for plant macrofossil analysis, probes interval was $20 \mathrm{~cm}$.

Samples were processed for pollen analysis using the pollen extraction procedure developed by Grichuk [7]. The 


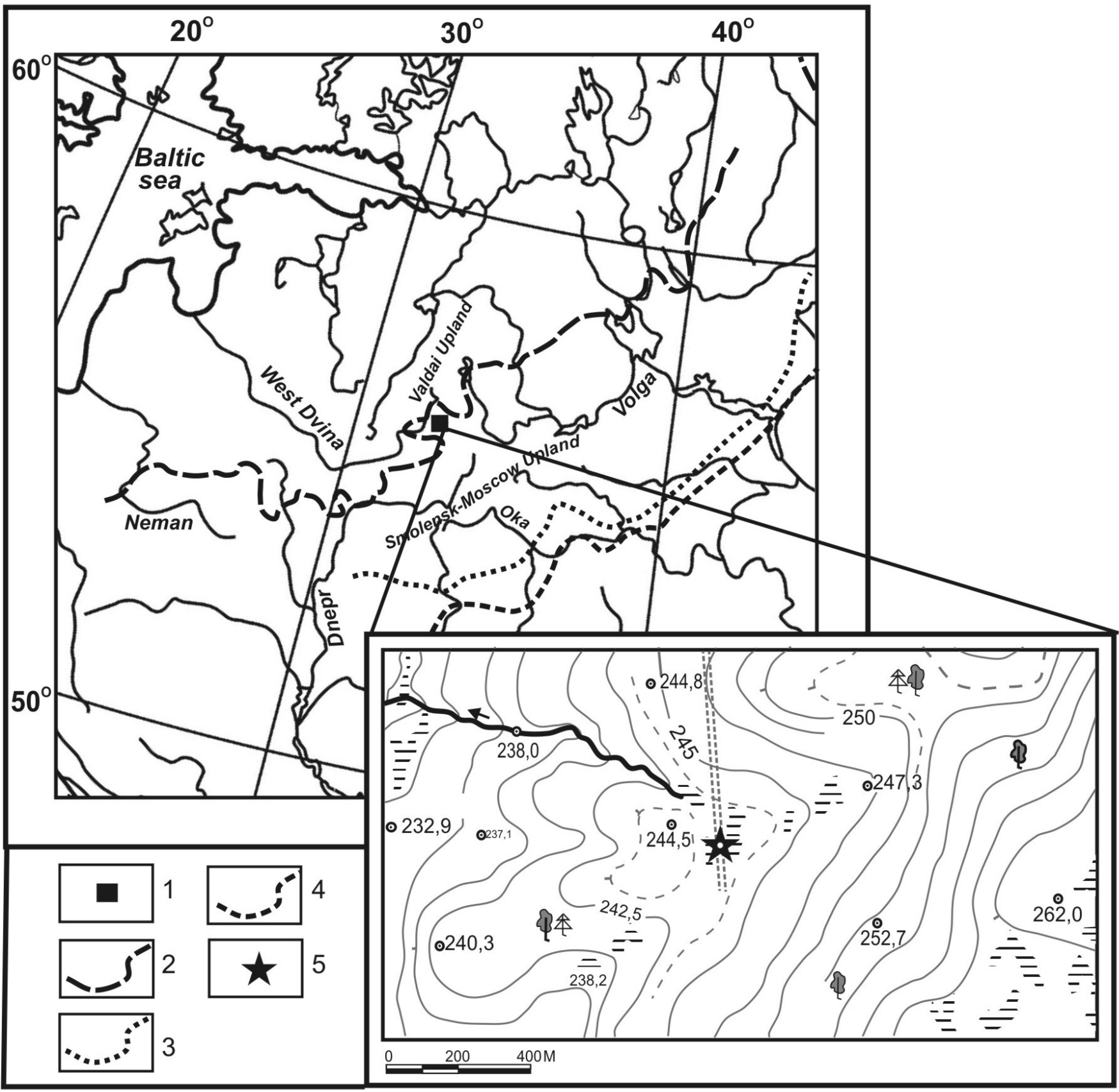

Fig. (1). Location of the Central Forest State Natural Biosphere Reserve. 1. - position of the Reserve; 2-4. - Main glacial boundaries [8]: (2). Late Valdai (Weichselian), (3). Moscow (Late Saalian), and (4). Dnieper (Early Saalian) glaciation; 5. - local position of section.

treatment included separation by heavy liquid (cadmium iodine) with the net weight of $2.2 \mathrm{gram} / \mathrm{cm}^{3}$. A minimum of 500 pollen grains and spores per sample was counted. Relative frequency of pollen was calculated based upon the total terrestrial pollen sum, arboreal pollen (AP) plus nonarboreal pollen (NAP). Pollen of the aquatic plants and spores were also calculated in relation to this sum (AP+NAP). Pollen diagrams were compiled using Tilia and TiliaGraph programs [9].

The samples for macrofossil analysis were disintegrated with water and washed through a sieve with $0.25 \mathrm{~mm}$ mesh. Plant remains were picked out under binocular microscope.
The analysis of fossil flora was realized using Ellenberg's ecological scale [10]. For every species there is certain point depending on its ecological demands. Ellenberg's ecological scale includes six parameters: temperature, continentality, moisture supply, shade tolerance, reaction and nitrogen values in soils. In the presented work the first three parameters have been analyzed and discussed.

The parameter of temperature value indicates the modern occurrence of species in regions distinguishing by their heat supply: from Mediterranean to Arctic area and from lowland to upper levels of mountains. Plants, indicators of cold climate, growing only in alpine and arctic regions, are attributed to the lowest point (1). The maximal value (point 


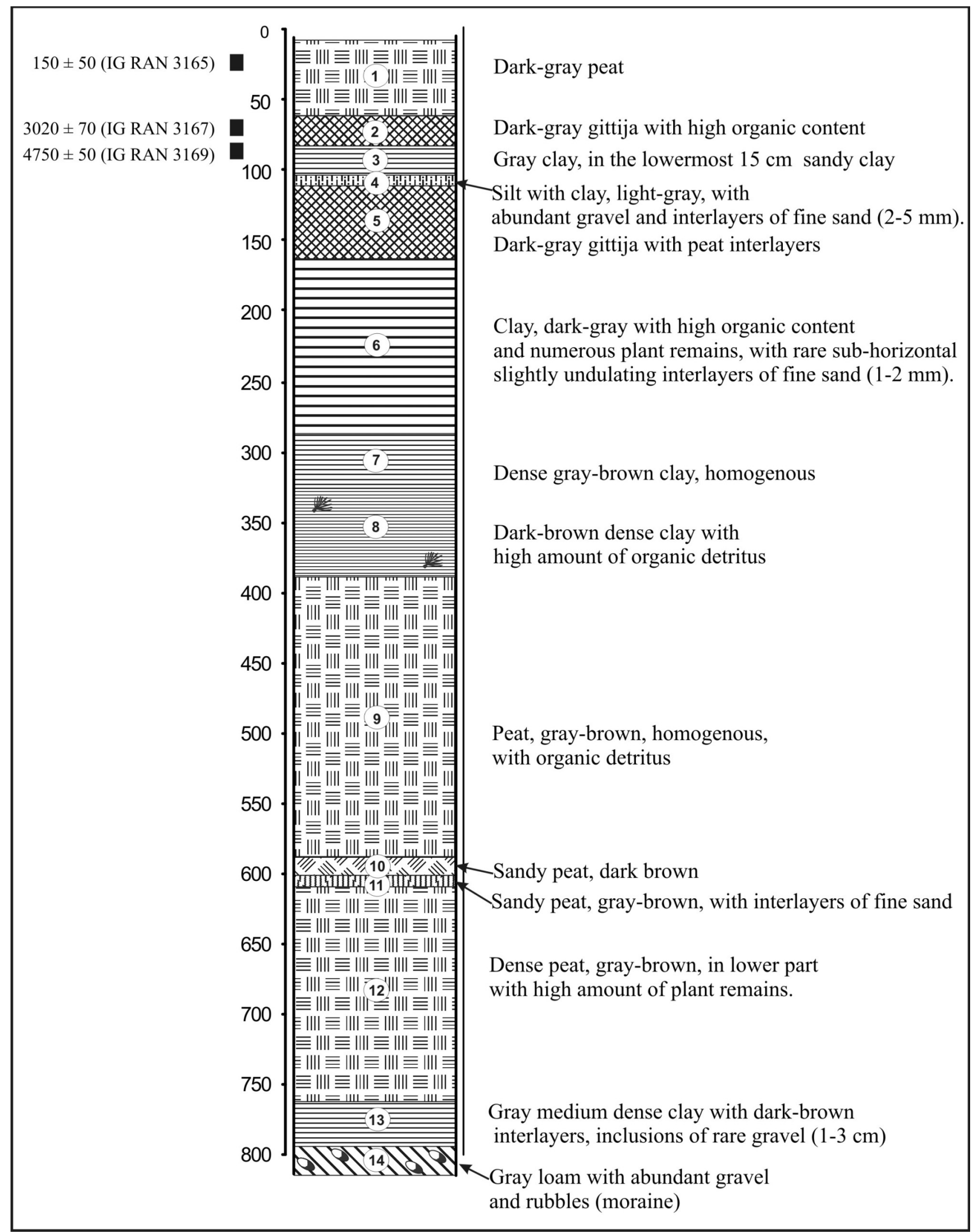

Fig. (2). Composition of the sediments in the section.

9) is corresponded to species of the warmest areas in the Central Europe and Mediterranean.
The parameter of continentality shows distribution of plants from Atlantic coast (point 1) to inner region of Eurasia (point 9), with special emphasis of their dependence on the temperature amplitude. Moisture value characterize the 
gradient of occurrence of plants from dry rocky soils (point 1) to dump (point 7) and also this parameter include plants of water-saturated localities (point 9-11) and submerged species (point 12).

The lists of species revealed from pollen and macrofossil data of the section were compiled for every $10 \mathrm{~cm}$ layer. The mean values of each parameter were calculated for whole section. As a result we have several curves these reflect main tendencies of landscape dynamics.

\section{RESULTS}

\section{Pollen Analysis}

The Late Pleistocene part of the pollen diagram has been divided into 13 local pollen assemblage zones (LPAZ) on the basis of changes in the composition of both pollen and spores (Fig. 3).

LPAZ $1(790-775 \mathrm{~cm})$ is characterized by low AP content; the part of trees (Pinus, Betula, Picea) does not exceed $50 \%$. Pollen of shrubs (Betula nana, B. humilis, Hippophae rhamnoides) is registered very often. In NAP group Artemisia, Chenopodiaceae, Cyperaceae pollen is dominant. Pollen of heliophytes (Helianthemum, Ephedra) is present.

In LPAZ $2(735-775 \mathrm{~cm})$ pollen value of trees and shrubs increased to $85-90 \%$, mainly by Pinus and Betula ones. Among shrubs Viburnum opulus, Sambucus racemosa, Frangula alnus, Lonicera are present in samples. In the upper part of the zone pollen of broad-leaved species appears.

AP in zone LPAZ $3(712-735 \mathrm{~cm})$ reaches $90-95 \%$. Oak and elm are dominant forest-forming trees. Quercus pollen curve forms a high peak: up to $25-30 \%$ of AP+NAP. Acer and Fraxinus pollen constantly occurs in zone 3 in small quantities, Carpinus pollen is registered as well. LPAZ 3 is characterized by a rapid increase in Alnus and Corylus pollen values, such peaks are typical for the Eemian (Mikulino) pollen diagrams in the East Europe [11].

LPAZ $4(585-712 \mathrm{~cm})$ is characterized by high amount of Alnus and Corylus pollen, which for other trees and shrubs decreased to $5-15 \%$.

LPAZ $5(505-585 \mathrm{~cm})$ The most distinctive feature of pollen spectra in this zone is a high rise of Carpinus frequency $(17-23 \%)$, though pollen of broad-leaved trees Quercus, Tilia, Ulmus, Fraxinus, Corylus (30-40\%), and Alnus (15-20\%). continues to play an important role in spectra. Pollen of Tilia platyphyllos occurs in this zone.

The assemblages of the LPAZ $6(435-505 \mathrm{~cm})$ are dominated by Picea (up to 55\% from AP+NAP in the lower part of the zone). At the same time both relative frequencies of broad-leaved trees pollen are reduced significantly as compared to previous zone. The permanent components of pollen spectra are cold-tolerant shrubs (Betula humilis, B. nana, Alnus: Alnaster type). Although AP content in zone is still relatively high (above $80 \%$ ), these changes in pollen spectra indicate a significant cooling of climate. It is confirmed by the presence of a typical cold tolerant plant Selaginella selaginoides. Poaceae and Cyperaceae pollen is important in NAP group. The amount and variety of herbaceous pollen (Rosaceae, Ranunculaceae, Asteraceae, Apiaceae, Caryophyllaceae, Fabaceae, etc.) rise in this interval. Spores percentages both Polypodiaceae and Sphagnum vary from 10 to $20 \%$.

Pollen spectra of LPAZ $7(405-435 \mathrm{~cm})$ are characterized by an increase in NAP content (40-50\%) and a high diversity of the herbaceous plants. Poaceae and Cyperaceae dominate in this group. AP comprises Pinus and Betula. Pollen of Picea, Pinus sibirica and Larix occurs in a small amount.

Pollen values of trees and shrubs slightly increase in LPAZ 8 (325- $405 \mathrm{~cm})$. This group dominates by Betula and Pinus. NAP composition close to the previous zone. The high amount of algae (Pediastrum, Botryococcus) is typical for this zone.

Pollen assemblages of LPAZ 9 (305-325 cm) are marked by sharp decrease of AP content to $40 \%$. In this group pollen of Betula sect. Albae (a tree with an extremely high pollen productivity) prevails. Among shrubs, Salix, B. humilis, B. nana, and Alnus: Alnaster-type occur. In the herb group Cyperaceae, Poaceae and Ranunculaceae play a conspicuous role.

In zone LPAZ $10(285-305 \mathrm{~cm})$ pollen spectra are featured a noticeable increase of AP content (up to 65-75\%), mainly due to the tree birch pollen. Pollen of Betula sect. Albae comprises $65-80 \%$ of AP+NAP. Pollen of herbaceous plants typical for birch communities (Polygonum bistorta, Sanguisorba officinalis, Thalictrum, Valeriana) often occur in fossil flora. Pollen value of Artemisia and Poaceae decreased in comparison to the previous zone.

Pollen spectra of LPAZ $11(245-285 \mathrm{~cm})$ are very similar to that of LPAZ 9 (AP reduces to $30-40 \%$ ).

Pollen spectra in LPAZ $12(135-245 \mathrm{~cm})$ show an overall increase of AP content. Among tree pollen Betula is still predominant, reaching $80 \%$ in the lower part of the zone and Pinus sylvestris achieves maximum in the upper part. Pollen of Picea and Larix occurs, but not abundant. Pollen of cold tolerant shrubs forms a part in pollen assemblages. Group of spores includes Lycopodium annotinum, L. selago, Equisetum, Botrychium lunaria, Ophioglossum vulgatum, Selaginella selaginoides; the role of Sphagnum grows.

LPAZ $13(110-135 \mathrm{~cm})$ is characterized by the lowest AP content (15-20\%). Poaceae forms a peak, and Artemisia and Cyperaceae achieve maximum in this zone.

The upper $110 \mathrm{~cm}$ of profile was accumulated in the late phases of Holocene and is not considered in this publication.

\section{Plant Macrofossil Analysis}

Examination of buried organic sediments in the section (the interval $320-750 \mathrm{~cm}$ ) revealed the presence of plant macro remains belonging to 46 taxa (fruits, seeds, their parts, oospores, needles, etc.). Four local macrofossil assemblage zones (LMAZ) were distinguished according to their distribution in the section (Fig. 4).

LMAZ $1(750-680 \mathrm{~cm})$ predominated by aquatic plants. The remains of Salvinia natans (megaspores), Nuphar cf. lutea (fragments of seeds), Stratiotes aloides (spines), 


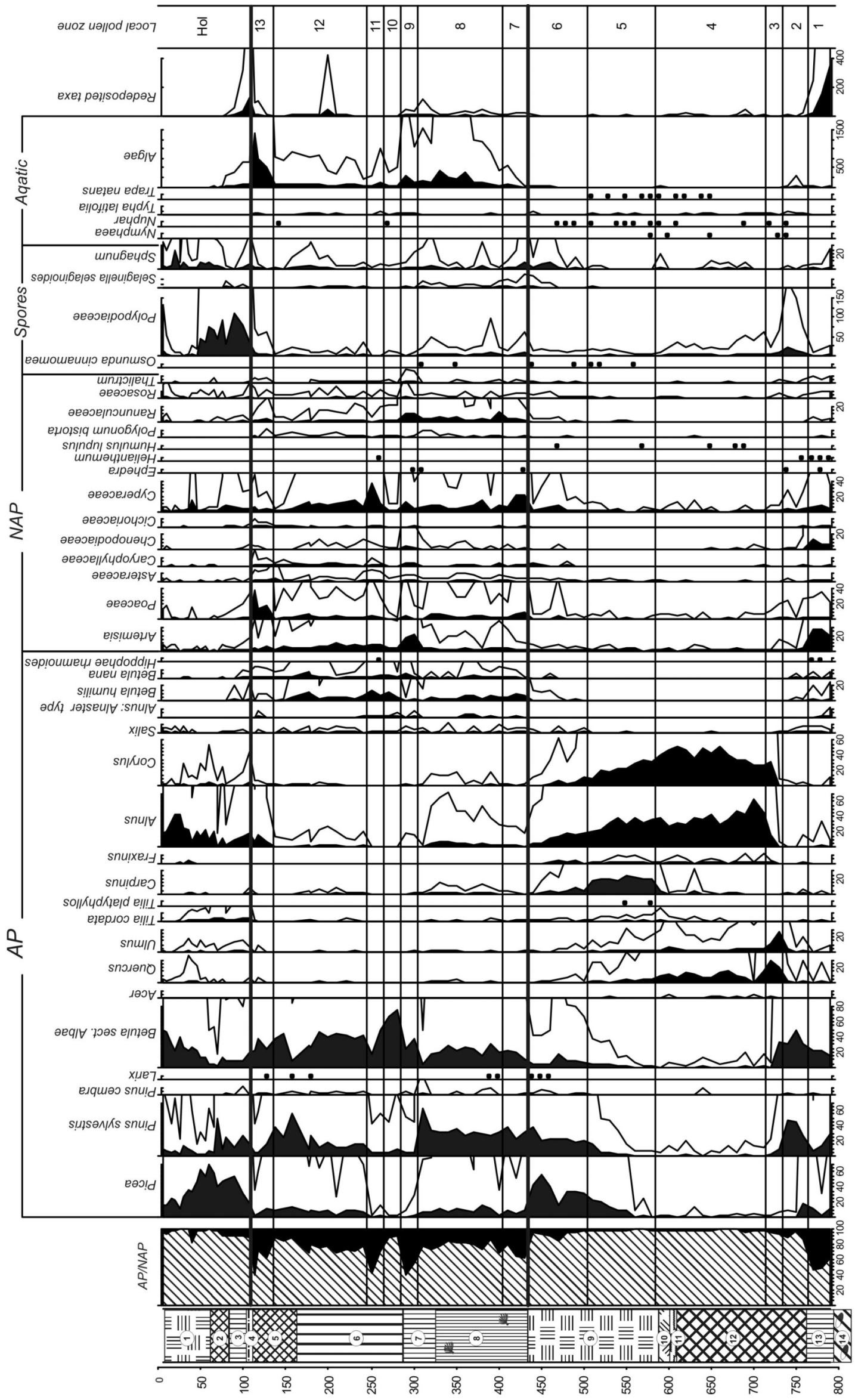

Fig. (3). Pollen diagram. Selected taxa $(\mathrm{AP}+\mathrm{NAP}=100 \%)$. Additional curves represent $\mathrm{x} 10$ exaggeration of base curves. 
Potamogeton natans (endocarps), Najas marina (seeds), Ceratophyllum demersum (fruits) and Characeae oospores have been identified. The shore and wetland plants are represented by tegmens of Typha and Alisma plantagoaquatica, Lycopus europaeus (nuts), Scirpus sylvaticus (nuts), Ranunculus sceleratus (fruits). The sediments also contain the needles of spruce and nuts of black alder and birch. The upper part of the zone (the interval $680-700 \mathrm{~cm}$ ) is marked by high amount of megaspores of Salvinia natans and tegmens of Typha sp.

In LMAZ $2(500-620 \mathrm{~cm})$ the remains of water plant are still abundant. The macrofossil assemblage is characterized by high value of Trapa natans (fragments of fruits) and mega- and microspores of Salvinia natans, fragments of seeds of Nuphar cf. lutea and Caulinia cf. flexilis, and plentiful of Potamogeton natans endocarps. The seeds of extinct species Brasenia holsatica are present. The littoral and wetland plants occur in greater abundance. Various species of sedges (Carex), Eleocharis palustris, E. ovata, Scirpus sylvaticus and Typha were registered. Rare nuts of Carpinus betulus, Alnus glutinosa, Betula sect. Albae and s ucanty needles of pine and spruce have been found in interval $560-580 \mathrm{~cm}$.

The macrofossil assemblage of samples from LMAZ 3 $(460-500 \mathrm{~cm})$ is noticeably poorer than that of the lower sample. The most frequent remains are these of Salvinia natans and Characeae oospores. The group of water and littoral plants is represented also by Ceratophyllum demersum, Potamogeton gramineus and Typha (upper part of the zone). Megaspores of Selaginella selaginoides seldom occur. The low diversity of taxa in this sample can be explained by taphonomical condition in the peat horizon.

LMAZ $4(325-440 \mathrm{~cm})$ is characterized by high amount of remains of Batrachium sp. (up to 300-350 seeds per sample) and oospores of Characeae. The megaspores of Salvinia natans and Isoetes lacustris, endocarps of Potamogeton filiformis and P. alpinus were rarely found. In this zone endocarps of extinct species Potamogeton dorofeevii have been identified. This species, noted in different periods of the Pleistocene, is typical for initial and latest phases of the interglacial and for interstadials with forest communities [12].

The sediments of the LMAZ 4 also contain a great number of megaspores of Selaginella selaginoides.

\section{Analysis of Fossil Flora}

The main trends of landscape development were determined on the base analysis of fossil flora using Ellenberg scale [10]. Three parameters were considered: heat supply, continentality and ground moisture supply. Despite the composition of fossil flora does not change considerably in the different part of section, these approach appears to be a sensitive method for palaeoecological studies (Fig. 5).

The curve of mean parameter, characterizing the temperature, show that the heat supply roses sharply from the beginning of the interglacial to its middle part, when it reached the maximal values.
The parameter, reflecting the plant reaction to degree of continentality of climate, show that species, noted for a rather oceanic region nowadays, took part in the vegetation during the middle part of the Interglacial.

The composition of fossil flora in the spruce phase (LPAZ 6) allows us to conclude about a rapid decrease of temperature, rise of continentality and significant growth of moisture supply. The amount of plants characteristic for damp habitats increased. The parameter of moisture value, obviously, suggests active processes of wetland development at the Interglacial $/$ glacial transition; that is in good agreement with the pollen and macrofossil studies.

The Early Weichselian (Valdai) glaciation is marked by complex pattern of natural processes, although the general trend to cooling with some quasiharmonic fluctuation revealed from several characteristics. In the coldest phases of the Valdai epoch determined by pollen data, one can observe some decrease of the mean index of temperature, at the same time the plants featured for continental climate become more abundant (the mean index of continentality rises).

\section{DISCUSSIONS}

Pollen and macrofossil data revealed from the section allow us to distinguish 8 phases of vegetation and climate development during the Eemian and the Early Weichselian. The Fig. (6) shows vegetation dynamics in the south Valdai Hills inferred from pollen data of the section in comparison with biostratigraphic zonation in the East European Plain [11] and Central and Eastern Europe [13].

Late glacial. Phase 1. Despite scarcity of palynological data for the end of Saalian (Dnieper) glacial epoch (the lowermost part of the profile; LPAZ 1), nevertheless we can suppose that at this time the territory of the Central Forest State Reserve were occupied by mixed vegetation, which included open birch and pine forests, cold-tolerant shrub communities (with Betula nana, B. humilis), meadows and bogs. Lithological data reflect an existence of the vast periglacial lake.

\section{Interglacial}

Phase 2. The transition to interglacial conditions encouraged the spread of spruce forest, and then light pine and birch-pine with well-developed shrub understorey (with Viburnum opulus, Sambucus racemosa, Frangula alnus, and Lonicera) communities occupied the area. Ferns (especially Pteridium aquilinum), grasses and mesophilic herbs were abundant in the ground cover. The role of shrub communities in the landscape increased significantly (LPAZ 2). During this phase pine forests were still predominant in the plant cover, but oak, elm, and later also ash penetrated the forest communities. Alnus and Corylus appeared in the forest understorey. Spruce forests were spread locally. The mesotrophic or, probably, eutrophic lake become shallow and changed into swamp. The typical interglacial species Najas marina, Salvinia natans, Brasenia appeared in aquatic assemblages. Climatic conditions in the end of the second stage were close to the modern ones in the south Valdai region. 


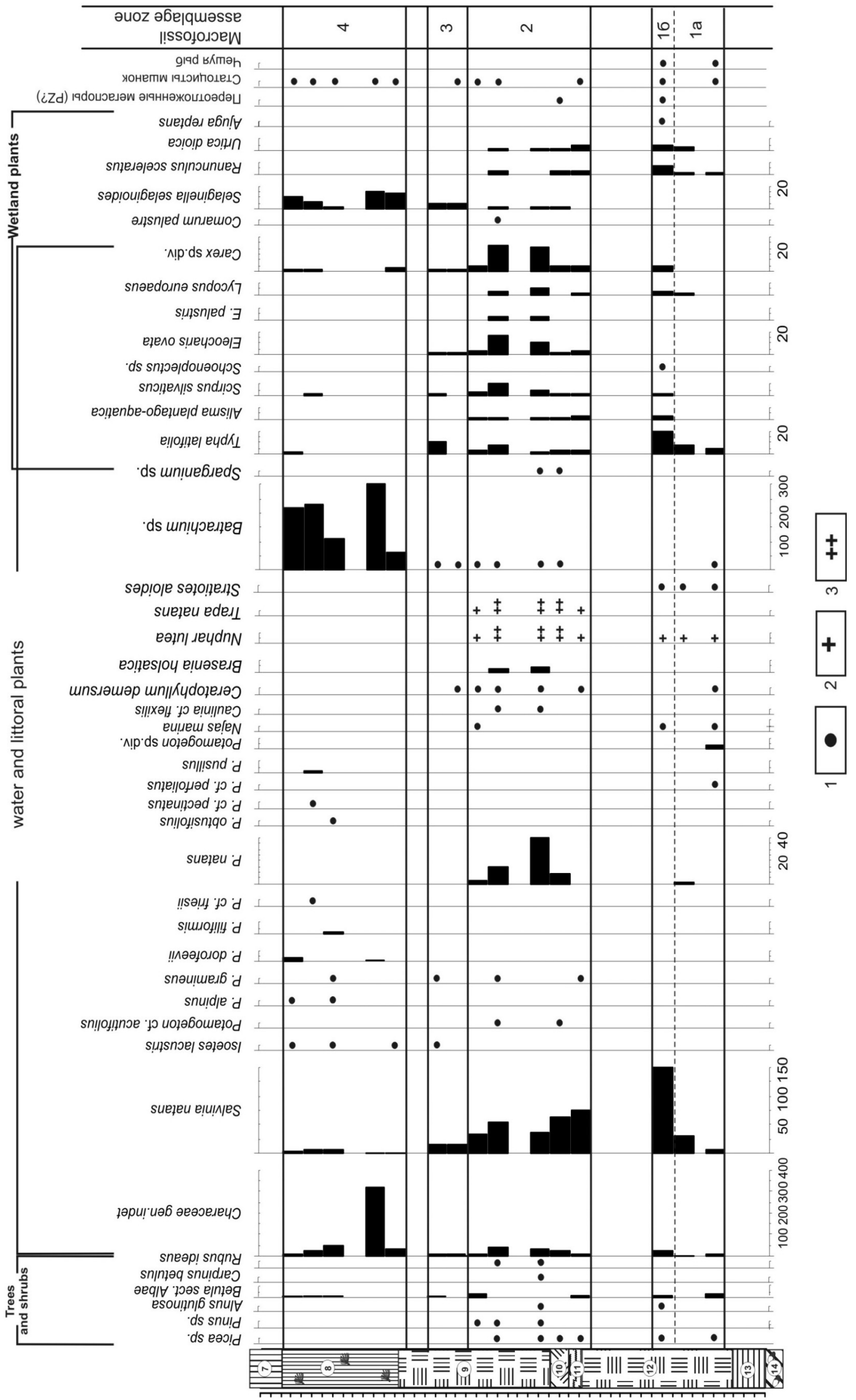

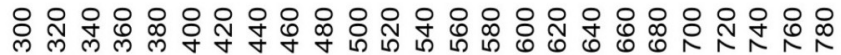

Fig. (4). Plant macrofossil diagram. 1.- rare macrofossils, 2. - rare fragments of macrofossils; 3. - numerous fragments of macrofossils. 
The zonal type of vegetation during phase 3 was oak forest (Quercus robur) with elm (Ulmus laevis, U. scabra), ash (Fraxinus excelsior), and maple (Acer platanoides). At the end of this stage hornbeam (Carpinus betulus) appeared in the forests. The characteristic feature of this stage is abundance of hazel (Corylus avellana). The important components of vegetation were communities of Alnus incana on the wet soil and swamped forests of A. glutinosa. Noteworthy is a presence of Trapa natans (its pollen and seeds are recorded in the samples). At present it grows south-west of the investigated area and characterized by vegetative propagation, while in the optimum phase of the last interglacial its range stretched into the south Valdai region.

The reconstructed vegetation and ecological composition of fossil flora (see Fig. 6) suggest a climate of this interval much warmer than the modern one.

Phase 4. Broad-leaved forests formed mainly by hornbeam, with linden (Tilia cordata, Tilia platyphyllos), oak and elm participating in their composition. Macrofossils of some aquatic plants, now extinct in this region but very typical for the optimum phase of the last interglaciation (Brasenia holsatica, Salvinia natans, Trapa natans, Caulinia cf. flexilis.), were found here. The finds of plants, growing at present in the regions with much warmer and milder climate than that of the investigated area as well as high mean Ellenberg's index of temperature and low one of continentality (see Fig. 5), allow us to correlate phase 4 with the Eemian (Mikulino) interglacial optimum.

Phase 5. Decreasing AP contents at this stage indicate a general reduction of the forested area. At the same time, spruce continued to spread over the area (so-called "upper maximum of spruce", [11]). The roles of broad-leaved trees fell gradually. Along with dark-coniferous forests open birch and pine-birch woodlands appeared. The frequent occurrence of micro- and megaspores of hypoarctic species Selaginella selaginoides can be considered as indicator of cool and moist conditions. The behaviors of curves of temperature, continentality, moisture and in Fig. (6) also reflect a progressive cooling and increasing of moisture.

During this stage swamps become widespread. The increase of Sphagnum spores content in samples and significant rise mean Ellenberg's parameter of moisture supply point to the active processes of peatland development in the Reserve. Probably, the latest phase of the interglacial were characterised by high ground moisture as a result of reduction of evaporation under cool climatic condition.

Similar composition of vegetation is typical for the modern southern taiga in West Siberia, under cool and relatively humid climate. Pollen assemblages of this phase of Interglacial point to some instability of plant cover. The relatively short interval of degradation of coniferous forests and development of birch and open meadow and swamp communities was identified at the end of warm stage. Similar oscillations towards the very end of the Eemian have been traced in a number of sections in Central and Eastern Europe by pollen and isotope-geochemical data [14].

\section{The Early Valdai (Weichselian) Glacial Epoch}

Phase 6. The composition of pollen and macrofossil assemblages of the beginning of cold time (subphase a, LPAZ 7) suggests that the boreal forest was replaced by complex vegetation. The plant cover comprised patches of spruce and larch-pine-birch woodlands and wet meadows. The communities of cold-resistant shrubs were widespread. Vegetation was close to the modern forest-tundra. In the pollen spectra of the next subphase b (LPAZ 8) AP content some increased, but there is no evidence about existence of closed forest. A cold tolerant but demanding to moisture supply species, Selaginella selaginoides, become more abundant.

The macrofossil data indicate, presumably, a positive shift in the moisture balance in this period that led to the rise of the lake level and reduce of organic content of water. Thickets of Batrachium were abundant of its marshy shores. The high amount of Chara algae is noteworthy, because in modern European lakes underwater meadows from Chara develop by the depth of 3-6 m [15] in clear and carbonatereach water.

At the same time the changes in character of sedimentation occurred. The similar features (changes from organic to clastic deposits) are typical for a number of lakes in the central part of the East European Plain [16].

Later (in subphase c, LPAZ 9) the role of forest significantly decreased, tree pollen practically despaired in pollen assemblages. The dominant of plant cover become steppe-like communities (Artemisia, Poaceae) and cold resistant shrubs.

The composition of flora at subphase d (PAZ 10) is very close to that of the previous one. Nevertheless, in response to a minor warming some changes in the vegetation took place. Birch open woodlands spread over the area, while the proportion of grassland slightly reduced. Heaths also became more abundant. Probably, the territory was still occupied by birch forest-tundra (or open woodland) with a thick shrub cover of dwarf birch, willow, and bush alder, though forest communities covered larger areas than previous subphase. This warming was short and had a small magnitude.

There are certain data indicating existence of similar small-scale warmings inside the first post Mikulino cold interval (Herning cooling) in the East European Plain. For example, there are 'birch intervals' in the sections Ples in the Upper Volga region [17].

During the final interval (subphase e, LPAZ 11) of considered phase open periglacial vegetation reappeared on the territory.

Environmental conditions of the earliest two subphases were much warmer and humid as compare to the latest ones. This interval (6a and $6 \mathrm{~b}$ ) can be considered as rather long transitional interval from typical Interglacial landscapes (spruce phase) to periglacial vegetation (subphases c-e). In especially cold and severe subphases $6 \mathrm{c}$ and $6 \mathrm{e}$ the forest communities disappeared completely. These cold intervals were separated by warming that was probably short 
52 The Open Geography Journal, 2010, Volume 3

Novenko and Zuganova

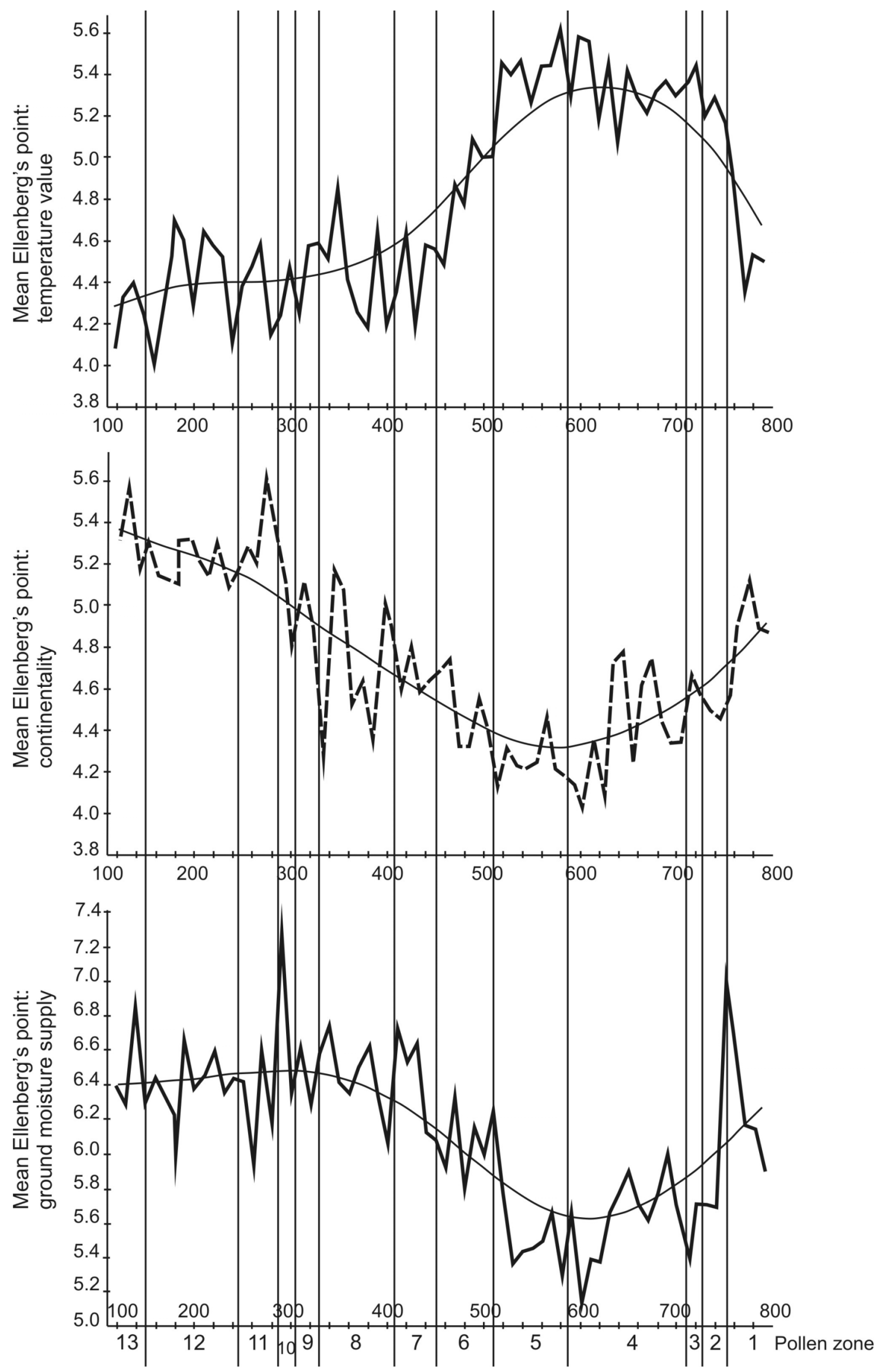

Fig. (5). Changes of the main characteristic of landscape, Ellenberg's ecological scale. 


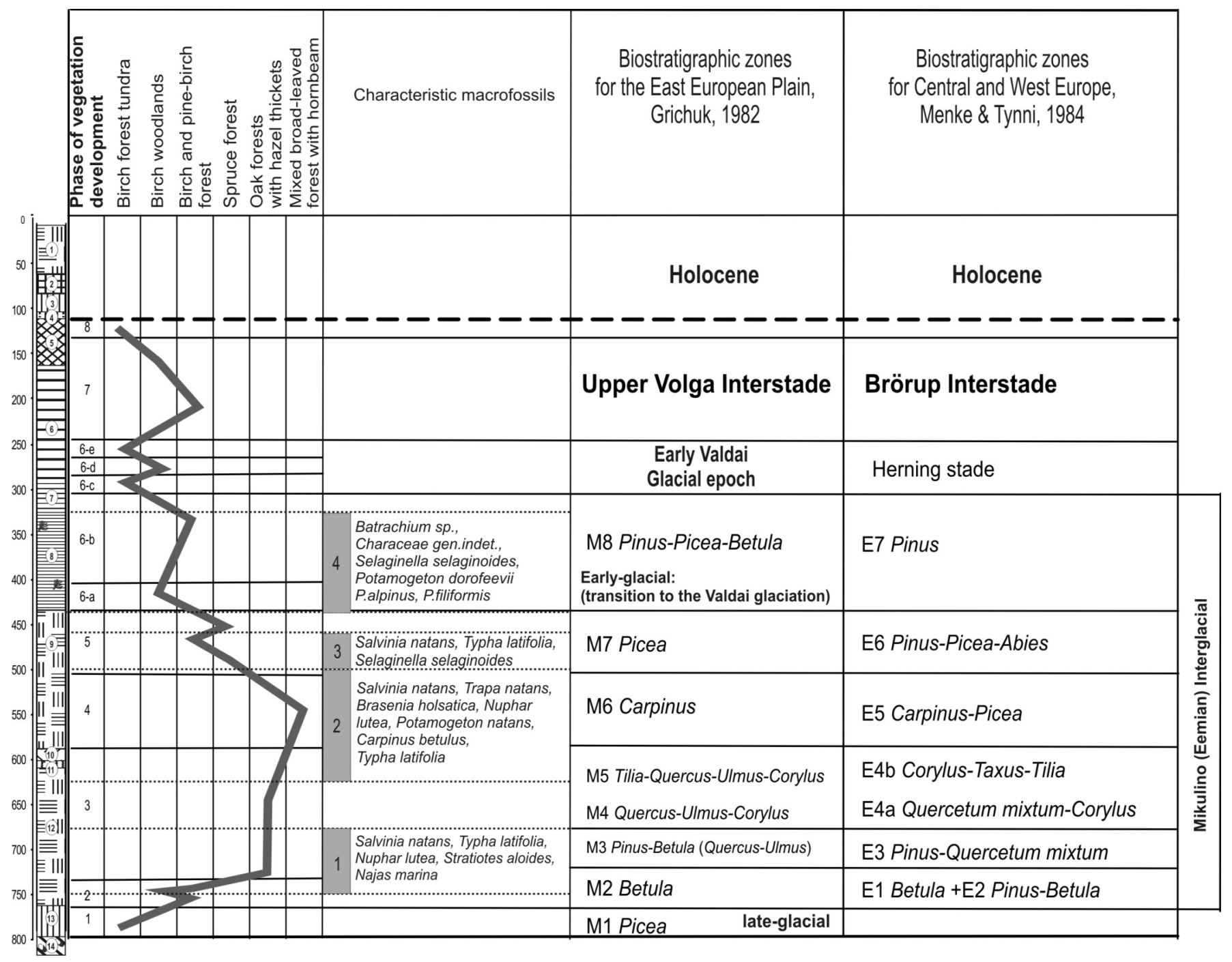

Fig. (6). Vegetation dynamics during the Eemian (Mikulino) Interglacial and the early stages of the Weichselian (Valdai) glacial epoch.

and had a small magnitude. There are certain data indicating existence of similar small-scale warmings inside the first post Mikulino cold interval (Herning cooling) in the East European Plain. For example, there are 'birch intervals' in the sections Ples [17] and Plescheevo Lake [18] in the Upper Volga region. Complex dynamics of environment process show that the climate of the initial part of this glacial epoch was characterized by inner instability resulting in the sequence of second-, and even third-order climatic oscillations expressed against the background of the overall trend toward cooling.

Phase 7, Interstade. Changes in pollen assemblages at this phase reflect a rapid afforestation of the area. Birch, pine and spruce forests similar to the contemporary middle taiga in West Siberia, were predominant during this interval. The role of shrub communities also increased. Changes in type of sedimentation occurred: lacustrine accumulation at this site ceased, and peat forming started once again. Probably these environment changes were brought about by a climate warming of the interstadial rank. By the composition of pollen assemblages and the flora this warming is similar to the Verkhnevolzhsky (Upper Volga) interstade, corresponding to the Brörup interstadial in West Europe
[13]. The Upper Volga interstade was described in the stratotype section Mikulino [19], and in a lot of sections in Russia, Byelorussia and Lithuania [20-22], where the Early Weichselian (Valdai) deposits overlay the Eemian (Mikulino) sediments in the continuous sequences.

Phase 8 (PAZ 13). Pollen data indicate an existence of cold tree-less landscape (wormwood and grasses dominated). The high proportion of redeposited pollen in samples, probably, suggests intensive erosion of soil, still poorly protected by vegetation. During this time loess-like deposits accumulated over the area under consideration. In this section the thickness of loess-like silt and clay does not exceed $15 \mathrm{~cm}$, although their mean thickness in the area of the CFSNBR is $60 \mathrm{~cm}$, some traces of cryogenic deformation have been observed in this horizon in a number of points [23].

\section{CONCLUSIONS}

The pollen and macrofossil data on the lower layers of this sequence recorded a typical succession of forest communities during the Eemien (Mikulino) Interglacial. Pollen profile indicates the broad-leaved forest dominated by oak and elm, with participation of lime, maple and ash in the 
first half of the Interglacial and hornbeam at the optimum phase. During the second half of warm period, the gradual cooling and increasing humidity of climate brought about a development of dark-coniferous communities.

According to data available, the first post-Eemian cold epoch comprised several short stages of cooling and weak climatic ameliorations. This minor warming is indicated by an increase in arboreal pollen percentages. In these phases, birch open woodlands spread over the area, while the proportion of grassland was slightly reduced. There are certain data indicating existence of similar small-scale warmings inside the Herning cooling all over Europe. Probably, the climate of the initial part of the glaciation had instable character with short-term climatic oscillations expressed against the general trend to cooling.

This first Early Weichselian cold stage was followed by a climate warming of the interstadial rank. Changes in pollen assemblages at this stage reflect a rapid afforestation of the area. Vegetation, similar to the contemporary middle taiga in West Siberia, was predominant during this period. By the composition of pollen spectra and flora, this warm interval in the section of the Reserve is similar to the Verkhnevolzhsky (Upper Volga) interstade, corresponding to the Brörup phase in West Europe.

\section{REFERENCES}

[1] Imbrie J, Hays JD, McIntyre A, et al. The orbital theory of Pleistocene climate: support from a revised chronology of the marine $\delta 18 \mathrm{O}$ record. In: Berger A, Imbrie J, Hays J, Kukla G, Saltzman B, Eds. Milankovitch and Climate. Boston: Reidel 1984; pp. 269-305.

[2] North Greenland ice core project members. High-resolution record of Northern Hemisphere climate extending into the last interglacial period. Nature 2004; 431: 147-51.

[3] Brauer A, Allen RM, Mingram J, Dulski P, Wulf S, Huntly B. Evidence for last interglacial chronology and environmental change from Southern Europe. Proc Natl Acad Sci USA 2007; 104(2): 450-55.

[4] Hahne J, Kemle S, Merkt J, Meyer, K. Eem-, weichsel und saalezeitliche Ablagerungen der Bohrung Quakenbruck GE 2. Geolog Jahrb 1994; A (134): 9-69.

[5] Müller H. Pollenanalytische Undersuchungen und Jahresschichtenzählungen an der eem-zeitlichen Kieselgur von Bispingen/Luhe. Geolog Jahrb 1974; 21: 149-69.

[6] Sokolov NN. The interglacial deposits in Mezha river basin. Bull Comm Study Quat Period 1948; 12: 145-68.

[7] Grichuk VP. Method of treatment of the sediments poor in organic remains for the pollen analysis. Problemy fizicheskoi geografii 1940; 8: 53-8.

[8] Velichko AA, Faustova MA, Gribchenko YN, Pisareva VV, Sudakova NG. Glaciations of the East European Plain - distribution and chronology. In: Ehlers J, Gibbard PL, Eds. Quaternary glaciations-extent and chronology. Amsterdam: Elsevier 2004; pp. 337-54.

[9] Grimm EC. TILIA and TILIA*GRAPH.PC spreadsheet and graphics software for pollen data. INQUA: Working Group on Data-Handling Methods. Newsletter 1990; 4: 5-7.

[10] Ellenberg H. Vegetation Mitteleuropas mit den Alpen in okologischer, dynamischer und historischer Sicht 5. Aufl. Ulmer: Stuttgart 1996.

[11] Grichuk VP. Vegetation of Europe during late Pleistocene. In: Gerasimov IP, Velichko AA, Eds. Paleogeography of Europe during the last one hundred thousand years. Moscow: Nauka 1982; pp. 79-85.

[12] Velichkevich F, Mamakova K. Taxonomic revision of the collections of plant macrofossils from some localities of Poland now referred to the Vistulian glaciation. Acta Paleobotanica 1999; 39(1): 29-87.

[13] Menke B, Tynni R. Das Eeminterglazial und das Weichselfrühglazial von Rederstall/ Dithmarschen und ihre Bedeutung für die mitteleuropäische Jungpleistozän-Gliederung . Geolog Jahrb1984; Reihe A (76): 3-120.

[14] Boettger T, Novenko E, Velichko A, et al. Instability of climate and vegetation dynamics in Central and Eastern Europe during the final stage of the last interglacial (Eemian, Mikulino) and early glaciations. Quat Int 2009; 207: 137-44.

[15] Schafer W. The base of plant geography. Moscow: Inostrannaya literature-press 1959.

[16] Gunova VS. Palaeolimnology of the central part of the Russian Plain in Mikulino Interstadial. The problem of Pleistocene palaeogeography and stratigraphy. In: Kaplin PA, Sudakova NG, Eds. Moscow State University-press 2000; pp. 280-91.

[17] Borisova OK, Novenko EY, Velichko AA, Kremenetski KV, Junge FW, Boettger T. Vegetation and climate changes during the Eemian and early Weichselian in the upper Volga region (Russia). Quat Sci Rev 2007; 26: 2574-85.

[18] Lavrushin YA, Chistyakova IA, Eds. Problemy Stratigrafii Chetvertichnykh otlozheniy i Paleogeografiya Yaroslavskogo Povolzhya. Moscow: GEOS 2001.

[19] Grichuk VP. Fossil floras as the basis for the quaternary stratigraphy. In: Markov KK, Ed. Rel'ef i Stratigrafiya Chetvertichnykh Otlozheniy Severo-zapada Russkoi Ravniny. Moscow: Izdatel'stvo AN SSSR 1961; pp. 25-71.

[20] Chebotareva NS, Makarycheva IA. Geochronology of the natural changes in the glacial region of East Europe during the Valdai epoch. In: Gerasimov IP, Velichko AA, Eds. Paleogeography of Europe during the last one hundred thousand years. Moscow: Nauka 1982; pp. 16-27.

[21] Satkunas J, Grigiene A, Velichkevich F, Robertsson AM, Sandgren P. Upper Pleistocene stratigraphy at the Medininkai site, Eastern Lithuania: a continuous record of the Eemian-Weichselian sequence. Boreas 2003; 32: 627-41.

[22] Savchenko IE, Pavlovskaya IE. Muravian (Eemian) and early Poozerian deposits at Azarichi (Eastern Belarus). Acta Paleobotanica 1999; (Suppl 2): 523-7.

[23] Pusachenko YG, Koslov DN. Geomorphologic development of the central forest reserve. In: Yurtzeva OV, Ed. Trudy of the central forest state natural biosphere reserve. Tula: Grif and K-press 2007; pp. $125-160$. 